\title{
Technological parameters of water regulation at the cultivation of highly productive feed crops on drained lands of the humid zone of Ukraine
}

\author{
Voropay G. \\ Institute of Water Problems and Land Reclamation NAAS \\ 37, Vasylkivska Str., Kyiv, 03022, Ukraine \\ e-mail: voropaig@ukr.net \\ ORCID: 0000-0002-5004-0727
}

Goal. To develop technological parameters of water regulation for growing highly productive fodder crops (paise, amaranth, and fodder beans) on drained lands of the humid zone of Ukraine. Methods. Analytical and experimental on production plots of reclamation systems, mathematical modeling, and processing of experimental data. Results. Technological parameters of water regulation (norms of groundwater level and moisture in the root layer of the soil) for growing highly productive fodder crops (paise, amaranth, and fodder beans) on peat and mineral soils are determined. Permissible terms are established in which the reclamation system should ensure the removal of excess water and timely reduction of the groundwater level to the recommended indicators. It is determined that modern climate changes in the Polissia region of Ukraine are manifested in uneven distribution of precipitation during the growing season, abnormal jumps in average daily air temperature, and low night temperatures $\left(<10^{\circ} \mathrm{C}\right)$ in summer, which affect agricultural production, especially the cultivation of heat-loving crops. Under such meteorological conditions, while ensuring optimal reclamation regimes, the yield of paise, which is a thermophilic crop by biological features, in 2019 for all fertilizer options was the lowest compared to the average yield for 2016 - 2018. Conclusions. In the conditions of climate change to ensure optimal parameters of water regulation and humidification measures on reclaimed lands of Polissia and Forest-Steppe of Ukraine in dry periods it is necessary to provide an accumulation of sufficient volumes of water with maximum use of the accumulative capacity of reclaimed territories and available resources of surface water sources.

Key words: drainage systems, groundwater level, soil moisture, water regulation parameters. DOI: https://doi.org/10.31073/agrovisnyk202101-09

A promising direction in fodder production is the introduction of highly productive and profitable varieties of crops that could complement traditional fodder crops and which have significant adaptive potential for growing in difficult agro-climatic conditions of the humid zone (Polissya and Forest-Steppe) of Ukraine. This will increase feed production, reduce the cost of crop and livestock products [1].

As climate change on the planet as a whole leads to an exacerbation of droughts, which are characteristic of the Polissya and Forest-Steppe zones of Ukraine, the current problem is the rational use of water resources. Therefore, when forming the structure of the fodder group of crops on the basis of the range of their varieties and hybrids, it is important to introduce such crops that are characterized not only by high productivity but also drought resistance [2, 3].

An important place among the rare, but highly productive, fodder crops for growing on drained lands is occupied by paise, amaranth and fodder beans, the interest in which arose in the late 80 s of last century, but only in order to find protein fodder. So far, these cultures have not been widely used [3].

Existing domestic and world experience shows that the introduction into the production of paise, amaranth and fodder beans allows not only to provide livestock with high quality feed, but also to meet the needs of the food and pharmaceutical industries with valuable raw materials [1].

However, to obtain sustainable yields of paise, amaranth and fodder beans in field fodder production on reclaimed lands of the humid zone, it is necessary to develop optimal water regulation parameters (groundwater level and moisture in the root layer of the soil), which will provide the necessary reclamation regimes.

Analysis of recent research and publications. The study of the experience of growing paise, amaranth and fodder beans shows that they have significant adaptive and productive potential, a number of biological advantages and features that determine the prospects and feasibility of growing them in difficult soil and climatic conditions of drained lands [3].

In conditions of increasing aridity of the climate, the most promising is paise, as it belongs to the most drought-resistant millet. vyh cereals. According to world experience, due to its biological features in the near future without it will not do any fodder base $[2,4-7]$.

Amaranth is a valuable not only fodder, but also food and medicinal crop. The green mass of amaranth can be used in animal husbandry both in fresh form and for the preparation of silage and protein-vitamin concentrate. It is cultivated in a number of progressive farms mainly as a fodder crop. In the United States, Germany and some African countries, the possibility of growing amaranth grain on an industrial scale for the food industry is being studied [8-12].

In solving the problem of providing protein with fodder, a large role also belongs to legumes, namely fodder beans, which are not only a source of protein, but also good precursors for other crops in crop rotation. 
Nutritional properties allow the use of fodder beans for all species of animals in the form of meal, grass meal, silage, green mass [13-15].

Scientific results also indicate the prospects of growing paise, amaranth and fodder beans for green fodder and silage on radionuclide-contaminated drained peat soils of Western Polissya of Ukraine [4].

The purpose of research is to develop technological parameters of water regulation in the cultivation of highly productive fodder crops (paise, amaranth and fodder beans) on drained lands of the humid zone (Polissya and Forest-Steppe) of Ukraine.

Research methods. Research methods include meteorological observations, studies of the dynamics of groundwater levels and humidity in the root layer of the soil, determining the yield of paise, amaranth and fodder beans.

Measurements of groundwater levels were performed on pentads with a measuring tape. A plate drill (design of Northern Research Institute of Hydraulic Engineering and Land Reclamation) was used to install the wells.

To determine the humidity by thermostatic-weight method at the experimental sites, soil sampling was carried out every decade from the horizons $0-10,10-20,20-30,30-40$ and $40-50 \mathrm{~cm}$ (according to State Standard of Ukraine ISO 11272-2001). Soil samples were weighed on an electronic laboratory scale MW-II and dried at a temperature of $105^{\circ} \mathrm{C}$ in an oven $2 \mathrm{~B} 151$.

The research was conducted during 2016-2019 on the reclamation systems of the Sarny experimental field of the Institute of Water Problems and Reclamation of the National Academy of Agrarian Sciences of Ukraine (SEF NAAS) (peat-marshy array "Chemerne", Rivne region) and "Romen" (Sumy region). These objects, taking into account the natural and climatic conditions and structural and technological features of reclamation systems, are representative of the territory of the humid zone (Polissya and Forest-Steppe of Ukraine).

Research results. The basis for the development of technological parameters of water regulation in the cultivation of paise, amaranth and fodder beans are the results of field research to determine meteorological parameters (precipitation, air temperature), groundwater level dynamics (GWL) and soil moisture, which were conducted on reclaimed lands SEF (peat-marshy array "Chemerne") and system "Romen".

Meteorological parameters on the reclaimed lands of the peat-marshy array "Chemerne" and the "Romen" system were obtained based on the results of observations at the meteorological posts of the SEF NAAS and the reclamation system "Romen" and the Romen meteorological station (Sumy region).

It is established that the values of monthly precipitation and average monthly air temperature in the vegetation period of 2016-2019 on reclaimed lands systems of SEF (peat-marshy array "Chemerne") and "Romen" differ significantly from their long-term average values.

During the growing season (April-September) of 2016 175,6 $\mathrm{mm}$ of precipitation fell on the reclaimed lands of the peat-marshy array "Chemerne", which is $224,4 \mathrm{~mm}$ less than the long-term norm (93\% rainfall), and the average monthly air temperature was $+16.2^{\circ} \mathrm{C}$, which is $1.7^{\circ} \mathrm{C}$ higher than the long-term average. All months of the growing season are characterized by less precipitation compared to the average long-term norm (on average by $44 \%$ ).

During the vegetation period 2017 the amount of precipitation was $227,0 \mathrm{~mm}$, which is $173 \mathrm{~mm}$ less than the long-term norm (93\% precipitation). June and August were especially light (55 and $41 \%$ of the norm, respectively). The average monthly temperature of the growing season is $+15,5^{\circ} \mathrm{C}$ and exceeds the average long-term norm by $0.9^{\circ} \mathrm{C}$.

In 2018, the amount of precipitation during the growing season was $255.0 \mathrm{~mm}$, which is $145 \mathrm{~mm}$ less than the long-term norm ( $90 \%$ precipitation). The average monthly temperature was $+17,1^{\circ} \mathrm{C}$, which exceeds the average long-term norm by $2,5^{\circ} \mathrm{C}$.

During the vegetation period of $2019317,2 \mathrm{~mm}$ of precipitation fell, which is $82,8 \mathrm{~mm}$ less than the long-term norm ( $73 \%$ precipitation). The growing season is characterized by extremely uneven distribution of precipitation: in May, their amount was $125,8 \mathrm{~mm}$, which corresponds to almost two monthly norms; in June, August and September - less than the norm by 70,55 and $90 \%$, respectively (Fig.1).

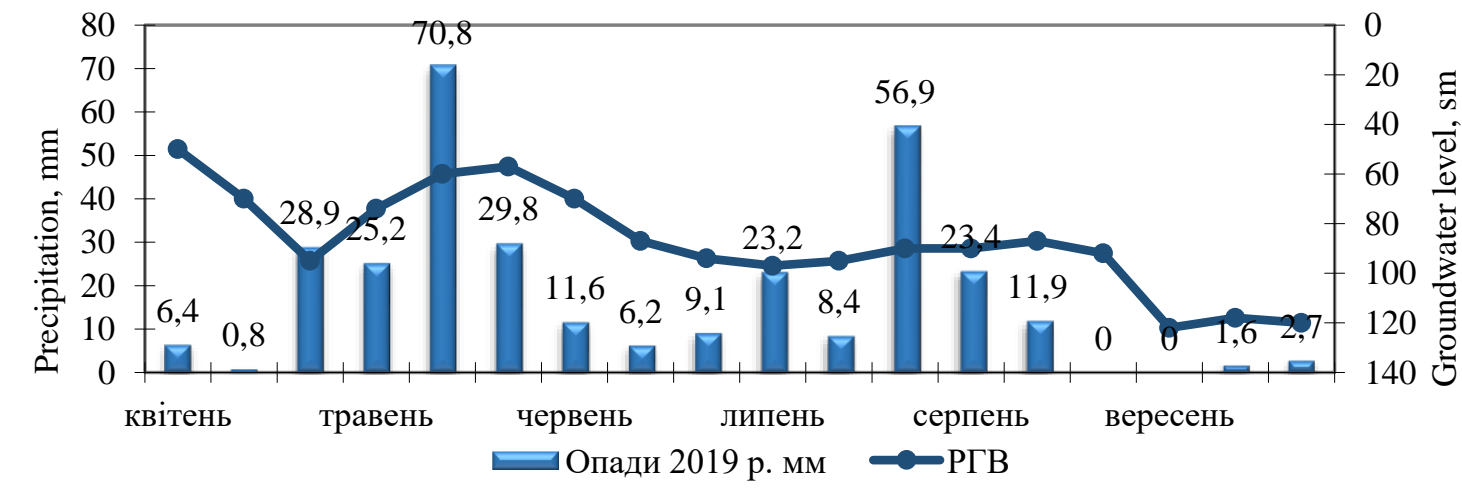

Fig. 1. Dynamics of precipitation and GWL on the reclamation system of SEF NAAS, 2019

The average monthly air temperature in April 2019 was higher than the long-term average by 0,8 ; in May - by 0,3 ; June - by 5,2; in July - by 0,2 and in August - by $1,2^{\circ} \mathrm{C}$. June was the hottest in the history of observations at the SEF meteorological post. July was marked by a long period (from 3.07 to 20.07) with minimal night temperatures $\left(<10^{\circ} \mathrm{C}\right)$. 
In general, the vegetation period of 2019 was marked by extremely uneven distribution of precipitation and jumps in average monthly temperature, especially in June and August, when their values exceeded the average long-term norm by $5,2^{\circ} \mathrm{C}$ and $1,2^{\circ} \mathrm{C}$, respectively, and abnormally low night temperatures $\left(<10^{\circ} \mathrm{C}\right)$ in July and August (Fig. 2).

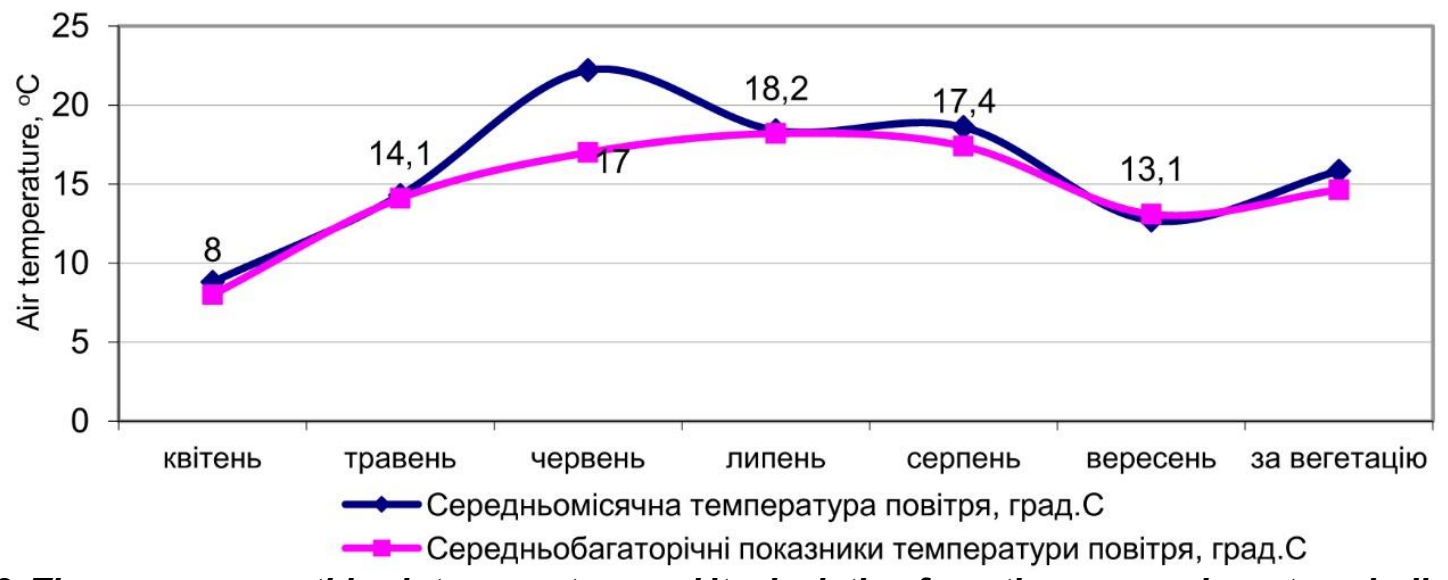

Fig. 2. The average monthly air temperature and its deviation from the average long-term indicators, ${ }^{\circ} \mathrm{C}$ (reclamation system SEF NAAS, 2019)

During the vegetation period of $2016409,8 \mathrm{~mm}$ of precipitation fell on the reclaimed lands of the "Romen" system (precipitation supply 15\%), which is $87,5 \mathrm{~mm}$ more than the long-term norm. Exceeding the long-term rainfall occurs in the first half of the growing season. The average monthly air temperature was close to the average long-term values and was $+15,7^{\circ} \mathrm{C}\left(0,6^{\circ} \mathrm{C}\right.$ less than normal).

During the vegetation period of $2017209,7 \mathrm{~mm}$ of precipitation fell, which is $112,6 \mathrm{~mm}$ less than the average long-term value (93\% precipitation). In all months except August, precipitation was less than the long-term norm. The average monthly air temperature was $1,6^{\circ} \mathrm{C}$ lower than in the long-term indicator and was $+14,7^{\circ} \mathrm{C}$. In May there were six days when the temperature reached minus values (from $-1{ }^{\circ} \mathrm{C}$ to $-5 \stackrel{\circ}{\circ} \mathrm{C}$ ), the last frost was recorded on May 22.

During the vegetation period of $2018305,1 \mathrm{~mm}$ of precipitation fell, which is $17,2 \mathrm{~mm}$ less than the average long-term value (55\% precipitation). The average monthly air temperature from April to July corresponded to the average long-term indicators, and in August and September it was slightly lower. In general, the average monthly air temperature was close to the long-term indicator and was $+16,5^{\circ} \mathrm{C}$.

During the vegetation period of $2019219,9 \mathrm{~mm}$ of precipitation fell, which is $102,4 \mathrm{~mm}$ less than the longterm norm ( $87 \%$ precipitation), and their amount was less than the norm in all months of the vegetation period, except May (more than the norm for $23,1 \mathrm{~mm}$ ), fig. 3 .

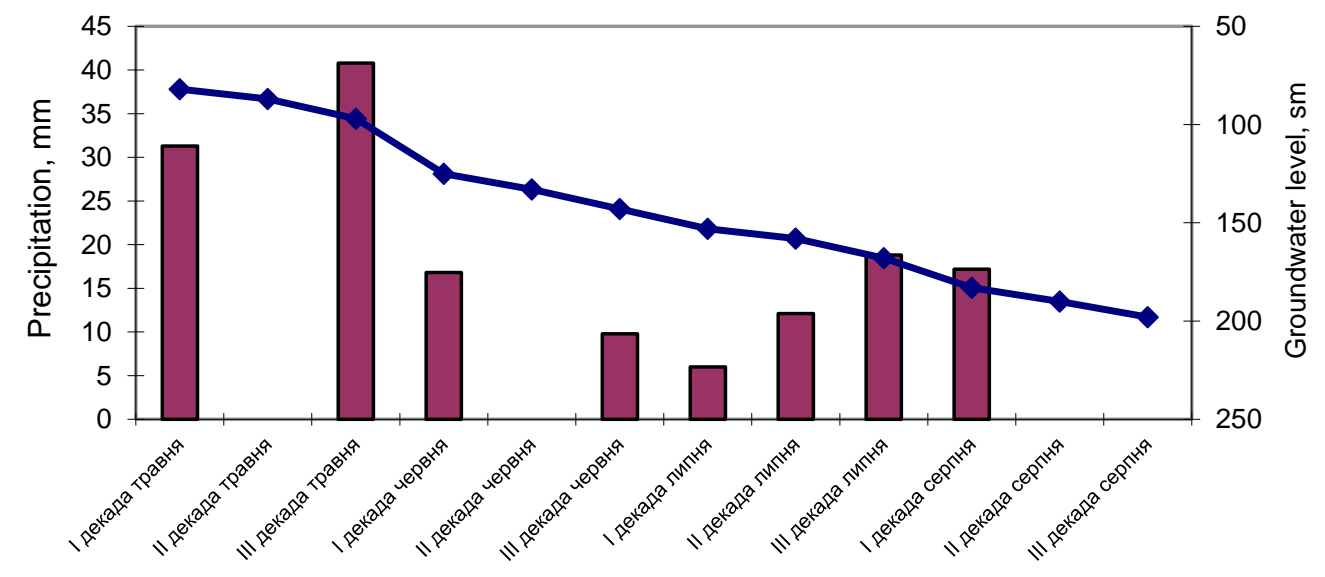

Fig. 3. Dynamics of precipitation and GWL, reclamation system "Romen", 2019

Average monthly air temperature in the growing season 2019 were lower than normal in all months except June (exceeding the norm by $1,3^{\circ} \mathrm{C}$ ). In general, during the growing season the average monthly air temperature was lower by $1,0^{\circ} \mathrm{C}$ compared to the long-term indicator and amounted to $+15,3^{\circ} \mathrm{C}$, fig. 4 .

The water regime on the reclamation systems of both sites was regulated by sluices thanks to a network of open canals. 


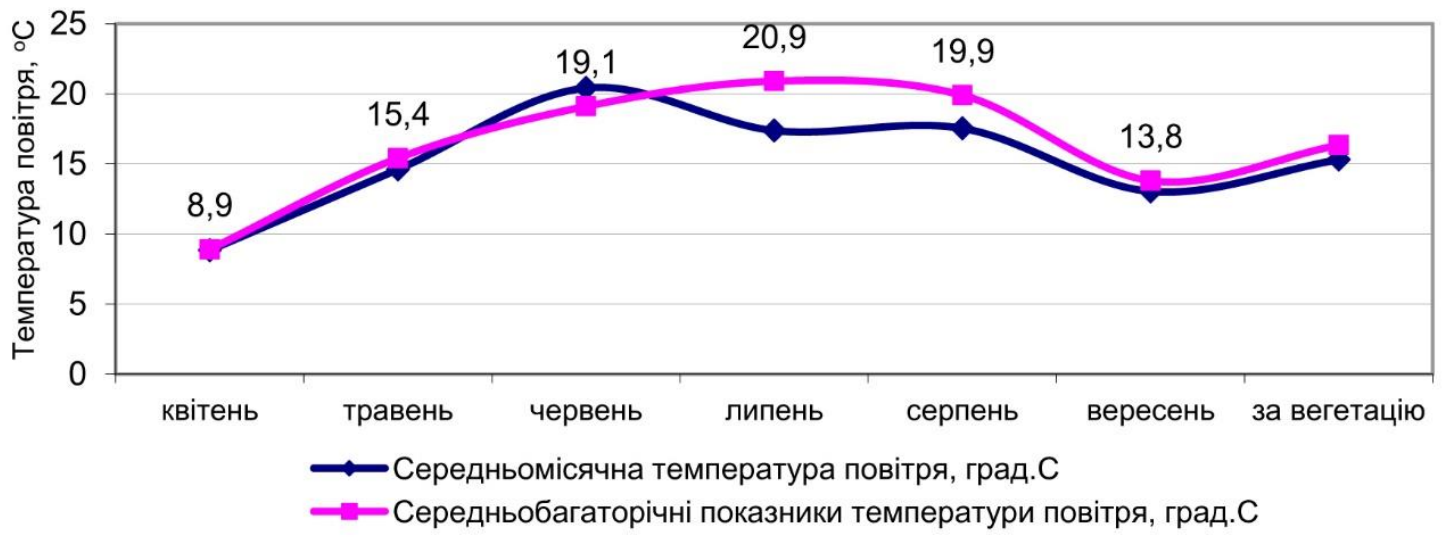

Fig. 4. Average monthly air temperature and its deviation from average long-term indicators, ${ }^{\circ} \mathrm{C}$; reclamation system "Romen", 2019

A study of the dynamics of GWL and soil moisture layer during the growing season in 2016 on the reclamation system SEF NAAS shows that during the growing season RGV was within $55-98 \mathrm{~cm}$ from the soil surface. During the second half of the growing season, the GWL was at the lower limit of the calculated range. Soil moisture in the experimental plots during the growing season of 2016 was close to optimal, which provided sufficient moisture reserves for growth and development of the studied forage crops. Inhibition of growth and development of the studied crops was not detected, which indicates that paise, amaranth and fodder beans can withstand drought well.

On the reclamation system SEF NAAS in 2017 during the growing season GWL was within $51-83 \mathrm{~cm}$ from the soil surface, which contributed to the formation of soil moisture within the calculated limits and also provided the necessary moisture reserves in the root layer of the soil. However, at the "Romen" gas station, due to insufficiently regulated water regime, the soil moisture was outside the calculated range.

During the vegetation period in 2018 the GWL on the reclamation system of SEF NAAS was within 35-76 $\mathrm{cm}$ from the soil surface. Humidity in the arable $(0-30 \mathrm{~cm})$ layer of the soil during the cultivation of paise was in the range of $54,0-73,4 \%$; fodder beans $61,3-80,0 \%$ of full moisture capacity (FMC); amaranth $64,2-75,3$ from FMC. In general, soil moisture during the growing season contributed to the formation of a sufficiently high yield of vegetative mass of the studied forage crops.

On the site of the reclamation system "Romen" in the growing season of 2018 GWL was in the spring in the range of $78-95 \mathrm{~cm}$, in the summer $-105-115 \mathrm{~cm}$ from the soil surface. At the end of the growing season, the optimal moisture in the root layer of the soil was provided by precipitation.

In the vegetation period of 2019 on the reclaimed lands of the peat-marshy array "Chemerne" the actual GWL was in the range: in April - 34-95, May - 38-78, June - 63-96, July - 95-110, August - 86-120, September - 116-124 cm from the soil surface.

Uneven distribution of precipitation during the growing season influenced the formation of GWL. However, due to the preparatory work on the reclamation system of the peat-marshy array "Chemerne" to restore the network of open canals and drainage, the removal of excess moisture at the pilot site in May and overall maintenance of GWL during critical growing seasons within acceptable limits was ensured.

Humidity in the active layer of soil $(0-50 \mathrm{~cm})$ during the cultivation of paise was in the range of $65,5-76,1$; amaranth $-66,9-77,4$; fodder beans $-67,3-73,2 \%$ of FMC. In general, the soil moisture in the layer of $0-50$ $\mathrm{cm}$ during the growing season was in the range of $65-75 \%$ of the FMC for cultivated crops.

In the vegetation period of 2019 on the reclamation system "Romen" the actual RGV was on average: in April -60, May - 88, June - 134, July, August - 190, September $-200 \mathrm{~cm}$ from the soil surface. In the spring, the provision of GWL ensured the passage of agricultural machinery, pre-sowing tillage and sowing of crops, but in the future the recommended GWL were not provided. This is explained by the fact that the amount of precipitation in all months of the growing season was less than normal. Under such conditions and in the absence of spring floods, it was impossible to accumulate enough water in the storage tank to moisten. The need for humidification measures falls on the period from July to September, but the filling of the tank for this period was insufficient to supply water to the experimental sites. During this period, the attraction of water resources from the Karabutov Reservoir also did not give the desired result. Karabutov Reservoir has a water surface area at a normal supporting level (NSL) of $5,02 \mathrm{~km}^{2}$ (mark NSL 145,5 m), a total capacity of 12,97 million $\mathrm{m}^{3}$ and a useful capacity of 11,97 million $\mathrm{m}^{3}$. The volume of water in the reservoir in 2019 ranged from 10.93 million $\mathrm{m} \mathrm{млн} \mathrm{to} 8,24$ million $\mathrm{m}^{3}$. Therefore, during the growing season, the filling of the reservoir to the level of useful volume was not achieved.

Water supply from the Karabutov Reservoir was carried out in two periods: from 26 to 29 June and from 13 to 16 August. The volume of water supplied for humidification was 0,24 and 0,12 million $\mathrm{m}^{3}$, respectively. However, such volumes were insufficient to replenish the moisture reserves of the active layer of the soil and provide the necessary water-air regime for crops.

Therefore, the possibilities of the available water sources (storage tank, Karabutivske reservoir), which are located in the area of reclaimed lands of the Romen system, were not used due to their insufficient filling with water resources. 
According to the results of research conducted in 2016-2019, it was found that during the growing season the requirements of paise, amaranth and fodder beans for moisture in the root layer of the soil change depending on their biological needs and current meteorological conditions.

It is determined that the critical periods for waterlogging of drained lands are spring floods and summerautumn floods, which are characteristic of the humid zone. In the spring, a necessary requirement is the timely reduction of GWL to the norm, which ensures the passage of agricultural machinery, pre-sowing tillage and sowing of crops.

For fodder beans and amaranth, the allowable time for removal of excess water from the soil surface is $0,5-1$; from the soil layer $0-0,25 \mathrm{~m}-1-2$; from the soil layer $0-0,50 \mathrm{~m}-2-3$ days, and for paise - respectively $1-2$; $2-4$ and $5-6$ days.

The recommended GWL for growing paise, amaranth and fodder beans on drained peat and mineral soils are also established, table. 1.

For mineral drained soils, the average moisture in the layer of $0-0.3 \mathrm{~m}$ at the beginning of sowing is $0,75-$ $0,8 \%$ of the total moisture content (FMC).

The recommended norms of soil moisture when growing paise, amaranth and fodder beans on drained lands are as follows: for peat soils optimal $-65-75 \%$, the lowest allowable in summer $-55-60 \%$; for mineral optimal $-65-80 \%$, the lowest allowable in the summer $-55-60 \%$ of FMC.

The results of research on the yield of vegetative mass of paise, amaranth and fodder beans depending on the fertilizer on the reclamation systems SEF (peat-marshy array "Chemerne") and "Romen" are shown in Fig. $5-8$.

1. Recommended norms of groundwater level when growing paise, amaranth and fodder beans on drained lands of the humid zone of Ukraine

\begin{tabular}{|c|c|c|c|c|c|c|c|}
\hline \multirow{2}{*}{$\begin{array}{l}\text { Vegetation } \\
\text { phase }\end{array}$} & \multicolumn{7}{|c|}{$\begin{array}{l}\text { Groundwater level, } \\
\text { nal; in the denominator }\end{array}$} \\
\hline & $\begin{array}{l}\text { pre-sowing } \\
\text { period }\end{array}$ & $\begin{array}{l}\text { seedlings- } \\
\text { tillering }\end{array}$ & tube exit & \multicolumn{2}{|c|}{$\begin{array}{l}\text { ejection of } \\
\text { the panicle }\end{array}$} & flowering & $\begin{array}{l}\text { ripening } \\
\text { seeds }\end{array}$ \\
\hline \multicolumn{8}{|c|}{ Paise } \\
\hline Peat soils & $0,50-0,55$ & $\frac{0,60-0,65}{0,65-0,70}$ & $\frac{0,60-0,75}{0,75-0,85}$ & \multicolumn{2}{|c|}{$\frac{0,60-0,75}{0,75-0,85}$} & $\frac{0,75-0,85}{0,90-0,95}$ & $\frac{0,75-0,90}{0,9-1,0}$ \\
\hline $\begin{array}{l}\text { Mineral } \\
\text { soils }\end{array}$ & $0,50-0,60$ & $\frac{0,60-0,70}{0,70-0,75}$ & $\frac{0,65-0,75}{0,80-0,85}$ & \multicolumn{2}{|c|}{$\frac{0,65-0,75}{0,80-0,85}$} & $\frac{0,80-0,90}{0,90-1,0}$ & $\frac{0,85-0,90}{1,0-1,1}$ \\
\hline \multicolumn{8}{|c|}{ Amaranth } \\
\hline $\begin{array}{l}\text { Vegetation } \\
\text { phase }\end{array}$ & $\begin{array}{l}\text { pre-sowing } \\
\text { period }\end{array}$ & $\begin{array}{c}\text { stairs- } \\
\text { appearance } \\
\text { of a real leaf }\end{array}$ & \multicolumn{2}{|c|}{$\begin{array}{l}\text { ejection of the } \\
\text { panicle }\end{array}$} & \multicolumn{2}{|c|}{ flowering } & ripening seeds \\
\hline Peat soils & $0,60-0,65$ & $\frac{0,60-0,65}{0,65-0,75}$ & \multicolumn{2}{|c|}{$\frac{0,60-0,70}{0,70-0,80}$} & \multicolumn{2}{|c|}{$\frac{0,65-0,80}{0,80-0,90}$} & $\frac{0,80-1,0}{1,0-1,1}$ \\
\hline $\begin{array}{l}\text { Mineral } \\
\text { soils }\end{array}$ & $0,50-0,60$ & $\frac{0,60-0,70}{0,70-0,75}$ & \multicolumn{2}{|c|}{$\frac{0,65-0,75}{0,75-0,80}$} & \multicolumn{2}{|c|}{$\frac{0,70-0,85}{0,90-1,0}$} & $\frac{0,85-1,0}{1,0-1,1}$ \\
\hline \multicolumn{8}{|c|}{ Fodder beans } \\
\hline $\begin{array}{l}\text { Vegetation } \\
\text { phase }\end{array}$ & $\begin{array}{l}\text { pre-sowing } \\
\text { period }\end{array}$ & $\begin{array}{c}\text { stairs- } \\
\text { appearance } \\
\text { of a real leaf }\end{array}$ & budding & \multicolumn{2}{|c|}{ flowering } & $\begin{array}{c}\text { formation } \\
\text { of beans }\end{array}$ & $\begin{array}{l}\text { ripening } \\
\text { seeds }\end{array}$ \\
\hline Peat soils & $0,55-0,65$ & $\frac{0,55-0,65}{0,70-0,75}$ & $\frac{0,60-0,65}{0,70-0,75}$ & & $\frac{0}{, 80}$ & $\frac{0,75-0,90}{0,90-1,0}$ & $\frac{0,90-1,0}{1,1-1,2}$ \\
\hline $\begin{array}{l}\text { Mineral } \\
\text { soils }\end{array}$ & $0,55-0,65$ & $\frac{0,60-0,70}{0,70-0,75}$ & $\frac{0,60-0,70}{0,70-0,75}$ & & $\frac{0,75}{, 90}$ & $\frac{0,80-0,90}{0,90-1,0}$ & $\frac{1,0-1,1}{1,1-1,2}$ \\
\hline
\end{tabular}

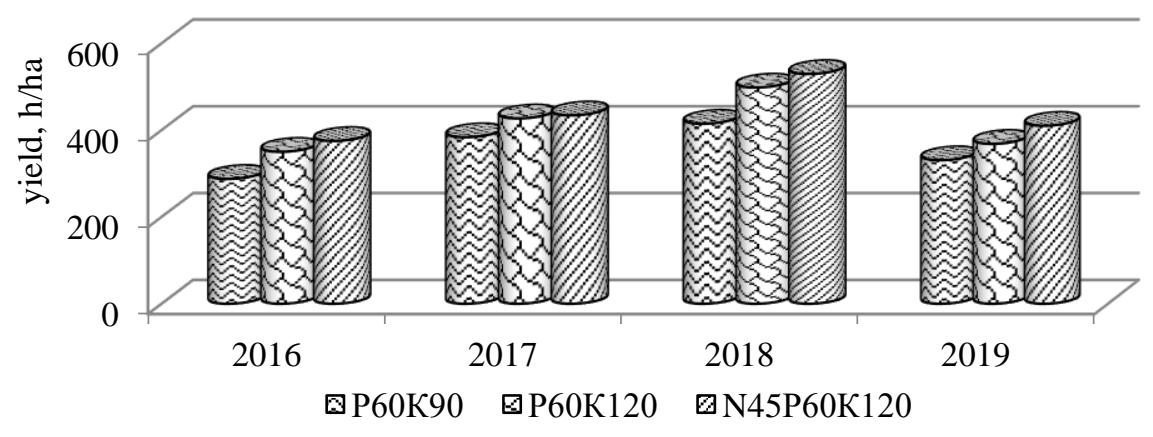

Fig. 5. Yield of paise depending on fertilizer, 2016-2019, reclamation system of SEF, peat-marshy array "Chemerne" 


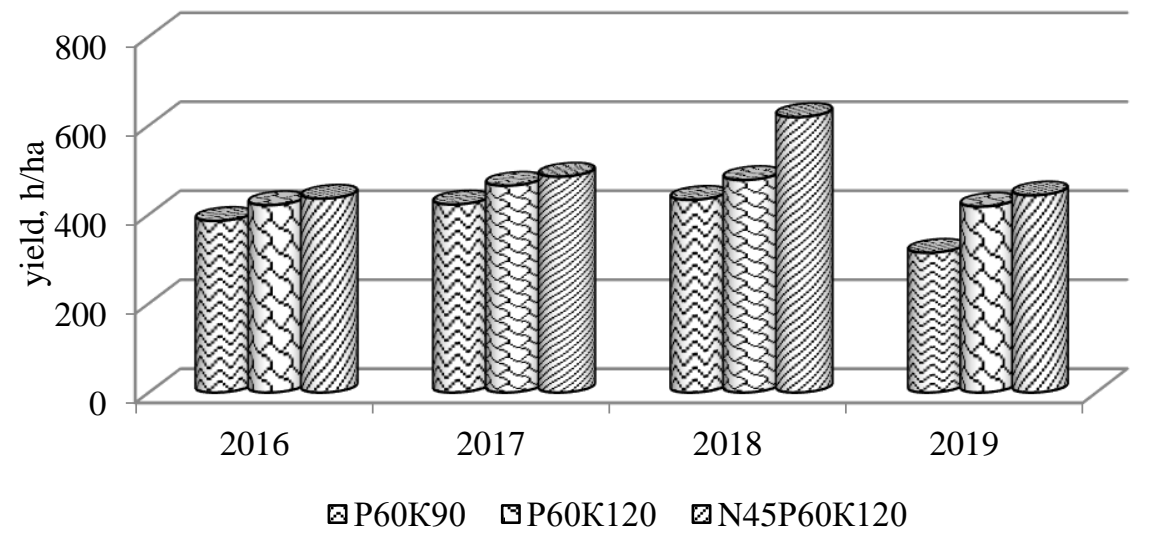

Fig. 6. Yield of amaranth depending on fertilizer, 2016-2019, reclamation system of SEF, peatmarshy array "Chemerne"

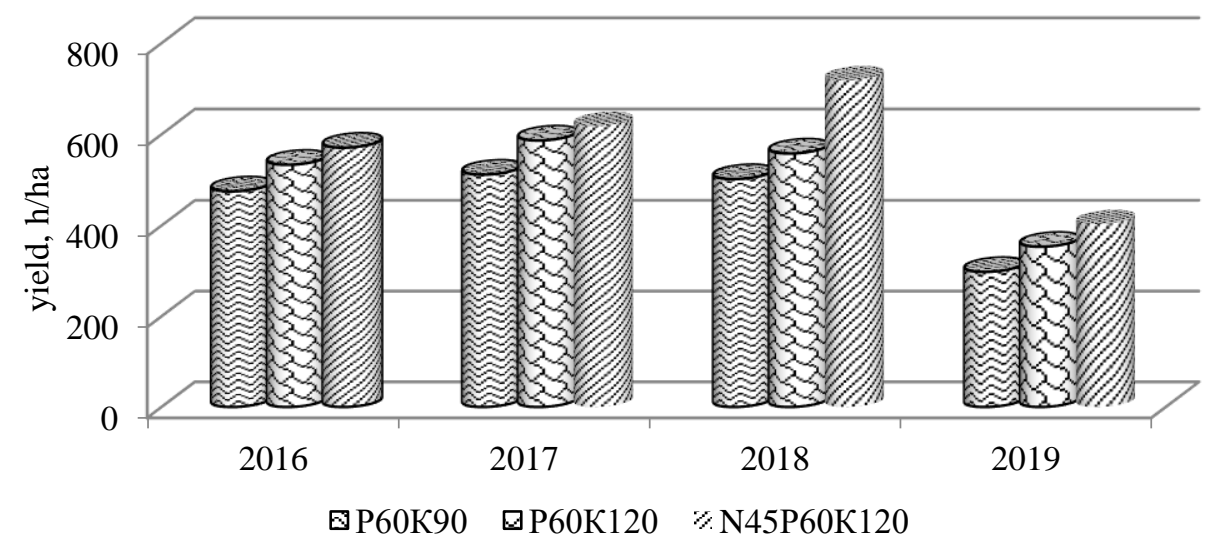

Fig. 7. Yield of fodder beans depending on fertilizer, 2016-2019, reclamation system of SEF

When applying phosphorus-potassium fertilizers in the norm of $\mathrm{P}_{60} \mathrm{~K}_{90}$, the yield of paise was $446,6 \mathrm{~h} / \mathrm{ha}$, the application of $\mathrm{P}_{60} \mathrm{~K}_{120}$ increased their yield by $13,6 \%$, and the application of complete mineral fertilizer increased by $29,1 \%$. When applying phosphorus-potassium fertilizers in the norm of $\mathrm{P}_{60} \mathrm{~K}_{90}$, the yield of amaranth was $388,6 \mathrm{~h} / \mathrm{ha}$, the application of $\mathrm{P}_{60} \mathrm{~K}_{120}$ increased their yield by $14,5 \%$, and complete mineral fertilizer increased by $27,4 \%$. When applying phosphorus-potassium fertilizers in the norm of $\mathrm{P}_{60} \mathrm{~K}_{90}$, the yield of vegetative mass of fodder beans in the period $2016-2019$ averaged $354,1 \mathrm{~h} / \mathrm{ha}$, application of $\mathrm{P}_{60} \mathrm{~K}_{120}$ increased it by $16,0 \%$, and complete mineral fertilizer - by $20,2 \%$.

When applying fertilizers in the norm of $\mathrm{N}_{30} \mathrm{P}_{30} \mathrm{~K}_{30}$, the yield of paise was $517,0 \mathrm{~h} / \mathrm{ha}$, which is $21 \%$ more than without fertilizers; amaranth $-392,0 \mathrm{~h} / \mathrm{ha}$, which is $15 \%$ more than without fertilizers; fodder beans $327,0 \mathrm{~h} / \mathrm{ha}$, which is $14 \%$ more than without fertilizers.

Studies of yields of paise, amaranth and fodder beans show that in 2019 on the reclamation system of the SEF peat-marshy array "Chemerne" the yield of these crops will be the lowest compared to the period of 20162018 , on average by $38 \%$, and in amaranth and fodder beans - by 15 and $10 \%$, respectively.

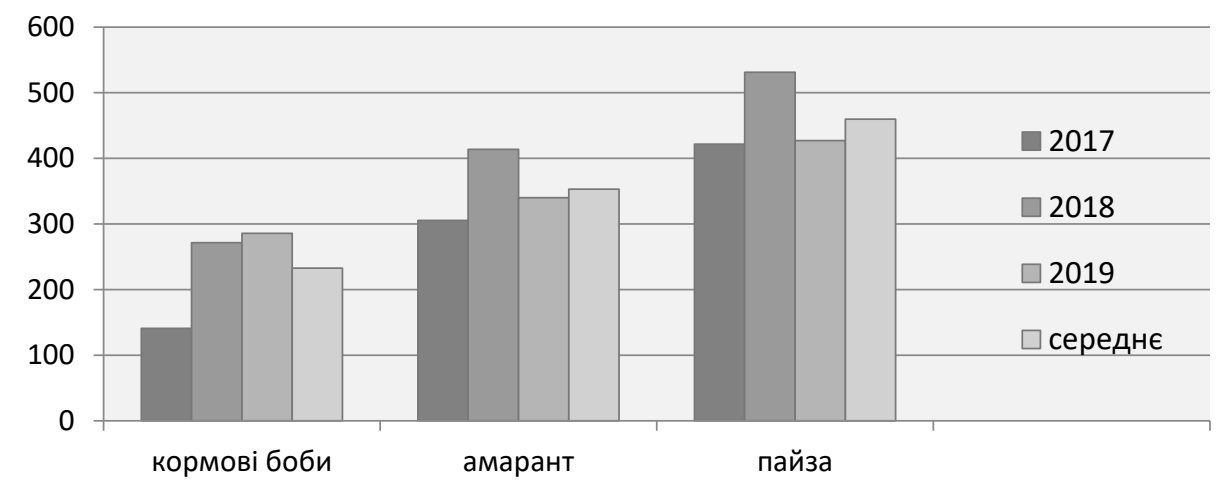




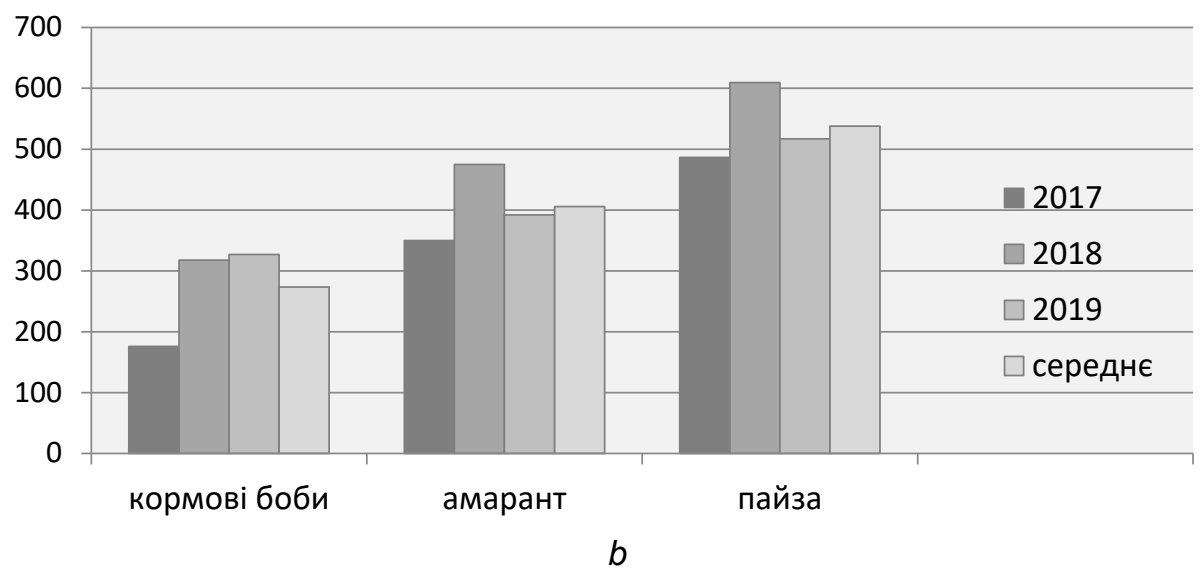

Fig. 8. Yields of paise, amaranth and fodder beans when grown: a - without fertilizers $b-$ $\mathrm{N}_{30} \mathrm{P}_{30} \mathrm{~K}_{30}$, h/ha; reclamation system "Romen", 2017-2019

This is due to the influence of special meteorological conditions in 2019 , which are manifested in the uneven distribution of precipitation, jumps in the average monthly air temperature and abnormally low night temperatures (in July and August). Under such meteorological conditions, however, with the provision of optimal reclamation regimes, the yield of paise, which is biologically heat-loving crop, in 2019 with all fertilizer options was the lowest compared to the average for the period 2016-2018.

\section{Conclusions}

According to the results of research conducted in 2016-2019, the technological parameters of water regulation (norms of groundwater level and moisture in the root layer of the soil) during the growing season in the cultivation of high-yield forage crops (paise, amaranth and fodder beans) on peat and mineral soils and the Forest-Steppe of Ukraine. Permissible terms have been set in which the drainage system should ensure the removal of excess water and ensure timely reduction of GWL to the recommended values.

It is determined that modern climate changes in the Polissya area (uneven distribution of precipitation during the growing season, abnormal jumps in average monthly air temperature and minimum night air temperatures in summer) have an impact on agricultural productivity in this area, especially on growing heat-loving crops.

It is determined that in the conditions of climate change to ensure optimal parameters of water regulation and wetting measures on reclaimed lands of Polissya and Forest-Steppe of Ukraine in dry periods it is necessary to provide accumulation of sufficient volumes of water with maximum use of accumulating capacity of reclaimed territories and available resources of surface water sources outside the drainage systems.

\section{References}

1. Yatsyk, M.B., Voropai, H.V., \& Kika, S.M. (2017). Dosvid ta perspektyvy vyroshhuvannia vysokoproduktyvnykh kormovykh kultur (paisy, amarantu ta kormovykh bobiv) na osushuvanykh zemliakh $\checkmark$ umovakh zmin klymatu [Experiences and prospects for growing high-yield fodder crops (barnyard, amaranth and fodder beans) on drained lands under climate change]. Land reclamation and water management, 105, 61-66. [in Ukrainian].

2. Stetsjuk, M. (2015). Perspektyvna paiza [The prospect barnyard]. The Ukrainian Farmer, 13 May, 90. [in Ukrainian].

3. Koval, S.I., \& Zosymchuk, O.A. (2014). Produktyvnist lanok kormovykh sivozmin z maloposhyrenykh kormovykh kultur na osushuvanykh torfovykh gruntakh Zakhidnoho Polissia [The productivity of links of forage crop rotations is from incurrent use not fogger crops on the drained peat soils of Western Polesye]. Bulletin of the National University water management and nature management study, 65(1), 64-72. [in Ukrainian].

4. Sosymchuk, O.A., \& Sosymchuk, M.D. (2009). Vyroshhuvannia maloposhyrenykh I netradytsiinykh kormovykh kultur na osushuvanykh torfovykh gruntakh Zakhidnoho Polissia [The growing in current use not and unconventional fogger crops on the drained peat soils of Western Polesye]. Bulletin of Lviv National Agrarian University. Agronomy series, 13, 434-440. [in Ukrainian].

5. Shevtsova, L.P., Bashynskaia, O.S., \& Shhukin, S.A. (2015). Paisa - netraditsyonnoe, no tsennoe rastenie [Barnyard is an unconventional, but valuable plant]. New and non-traditional plants and prospects for their use, 11, 90-93. [in Russian].

6. Sosymchuk, O.A. (2012). Kormova ta nasinneva produktyvnist paizy osushuvanykh torfovykh gruntakh Zakhidnoho Polissia [The feed and seed productivity of barnyard on the drained peat soils of Western Polesye]. Intensification of technologies - a way to increase the efficiency of agriculture: materials AllUkrainian scientific-practical Internet conference. Rivne, 48-51. [in Ukrainian].

7. Korzun, O.S., Anokhina, T.A., Kadyrov, R.M., \& Kravtsov, S.V. (2011). Vozdelyvanie prosovidnykh kultur v Respublike Belarus [The growing millet plant in Republic of Belarus]. Grodno: GGAU. [in Russian].

8. Voitashenko, D.P. (2006). Produktyvnist amarantu zernovoho napriamku zalezhno vid umov zvolozhennia ta norm mineralnykh dobryv [The productivity of the amaranth of grain- growing directiondepending on the terms of moistening and norms of mineral fertilizers]. Irrigation agriculture. Kherson: Ailant, 45, 48-52. [in Ukrainian]. 
9. Onyango, C.M., Imungi, J.K., Mose, L.O., Harbinson, J., \& Olaf Van Koteen. (2009). Feasibility of commercial production of amaranth leaf vegetable by small scale farmers in Kenya. African Crop Science Conference Proceedings, 9, 767 - 772. [in English].

10. Hudkovska, N.B., \& Hoptsii, T.I. (2018). Urozhainist zerna amaranta zalezhno vid strokiv ta sposobiv sivby $\checkmark$ umovakh Livoberezhnoho Lisostepu Ukrauiny [Productivity of grain of amaranth is depending on term sand methods of sowing in the conditions of Left-bank forest-steppe of Ukraine]. Bulletin of KhNAU. Series "Crop production, selection and seed production, fruit and vegetable growing and storage", 2, 112-121. [in Ukrainian].

11. Hudkovska, N.B., \& Hoptsii, T.I. (2016). Vplyv strokiv sivby na skhozhist nasinnia amaranta v umovakh Livoberezhnoho Lisostepu Ukrauiny [Influence of sowing dates on the germination of amaranth seeds in the conditions of the Left-bank forest-steppe of Ukraine]. Bulletin of KhNAU. Series "Crop production, selection and seed production, fruit and vegetable growing and storage", 1, 194-204. [in Ukrainian].

12. Saratovskii, L.I., Ponomarenko, L.I., \& Miroshnichenko, L.A. (2012). Vliianie pochvenno-klimaticheskikh uslovii TsChR na produktivnost amaranta [The influence of soil and climatic conditions of the Central Black Earth Region on the productivity of various amaranth varieties]. Voronezh newspaper agrarian university, 4(35), 56-60. [in Russian].

13. Babii, S.I. (2011). Adaptyvna zdatnist sortozrazkiv bobiv kormovykh ta yikh ekolohichni parametry $v$ umovakh Pravoberezhnoho Lisostepu [Adaptive ability of fodder bean cultivars and their ecological parameters in the conditions of the Right-bank Forest-steppe]. Feed and feed production. Vinnytsia. Vinnytsia, 70, 24-29. [in Ukrainian].

14. Prytulenko, O.V., Batjuzhevskyi, Ju.N., Bratyshko, N.I., Hordiyenko, V.M., Klymenko, T.Ye., \&Alkhadzh Takhtukh Mukhamed Khasan (2004). Kombikormy z tsilym zernom zlakovykh v hodivli kurei-nesuchok [Compound feeds with whole grain cereals in the feeding of laying hens]. Poultry breeding, 54, 79-83. [in Ukrainian]

15. Onychko, V.I. (2010). Vplyv sortovykh osoblyvostei ta agrotekhnichnykh zakhodiv na vrozhainist zerna kormovykh bobiv $v$ umovakh pivnichno-skhidnoho Lisostepu Ukrauiny [Influence of varietal features and agrotechnical measures on grain yield of fodder beans in the conditions of the north-eastern forest-steppe of Ukraine]. Feed and feed production. Vinnytsia, 67, 51-58. [in Ukrainian]. 